Gerald P. Dwyer, Jr, a professor of economics at Clemson University, is a visiting scholar and R. W. Hafer is a research officer at the Federal Reserve Bank of St. Louis. Kevin L. Kliesen provided reasearch assistance.

\title{
Interest Rates and Economic Announcements
}

T ANNOUNCEMENT of some government statistic, like the latest unemployment rate or the nation's most recent trade balance, often is used as the rationale for observed changes in financial markets that day. One reporter, for ex. ample, suggests that

[iln the early 1980s, investors were overly concerned with credit and monetary figures, focusing on Federal Reserve data. These days, professionals are preoccupied with inflation, the dollar and the health of the economy. ${ }^{1}$

Another reporter points out the unsystematic nature of such interpretations with the wry comment that

[t]he trade deficit doesn't matter as much any more. At least, not to the stock market. At least not this month. ${ }^{2}$

Do announcements of government statistics systematically affect financial markets? There is a substantial literature on the relationship between interest rates and stock prices and announcements of the money stock. Overall, this evidence supports the conclusion that announcements of the money stock had an important influence on interest rates in the early $1980 \mathrm{~s}^{3}$
This influence arose when the Federal Reserve first announced in October 1979 that it would use the money stock as a target for monetary policy, then largely disappeared in 1982 and 1983 when the Federal Reserve moved away from monetary aggregate targeting. ${ }^{4}$

Existing studies of the relationship between interest rates or stock prices and announcements of other economic data find little evidence that either is affected by these announcements. For example, Pearce and Roley (1985) investigate the effect of unexpected changes in inflation and real activity on stock prices and find little response of stock prices. Hardouvelis (1987) examines this relationship for interest rates and stock prices and finds that they are systematically affected only by an. nouncements of the money stock.

One common aspect of these studies is that they examine subperiods associated with changes in monetary policy. Changes in policy regimes provide an obvious basis on which to expect changes in the effect of money stock announcements on financial markets. There is no obvious reason, however, for changes in the ef-
1Wallace (1988).

2Sease (1989).

3This is less obvious for stock prices. As Thornton (1989) has demonstrated, money announcements are not suffi- ciently important for stock prices to be reliably associated with changes in the money stock.

4 See Gilbert (1985) and Thornton (1988) for a discussion of the changes in operating procedures. 
fects of announcements of other economic data to occur only when the Federal Reserve changes operating procedures. ${ }^{5}$ It is quite possible that a temporal association between interest rates or stock prices and the announcement of a particular statistic is fleeting compared to estimates based on multi-year sample periods of about three years.

The purpose of this paper is to examine the temporal response of short- and long-term interest rates to announcements of certain key government statistics. Unlike previous studies, we do not constrain the investigation by using only time periods of alternative monetary policy operating procedures. Rather, we attempt to determine whether the different announcements vary in importance over different time periods, even as short as one year.

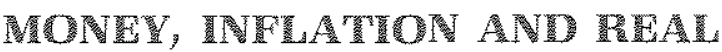

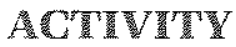

We examine the relationship between changes in interest rates and announcements using regressions that can be written as

(1) $\Delta R_{t}=\alpha+\beta U_{t}+\varepsilon_{t}$,

where $\Delta \mathrm{R}_{t}$ is the change in the interest rate in period $t, U_{t}$ is a vector of the unexpected parts of the announcements of some government statistics, $\varepsilon_{\mathrm{t}}$ is the error term, and $\alpha$ and $\beta$ denote the set of parameters to be estimated. We focus on the unexpected parts of the announce- ments because, when the change in the price of an asset like Treasury securities or stocks is measured over a short period, the change in the asset's price may be affected only by the unexpected part of the announcement. ${ }^{6}$ For the most part, previous empirical analyses indicate that changes in interest rates are systematically associated only with the unexpected part of weekly announcements of the money stock. ${ }^{7}$ In addition to the money stock announcements, we study the effects of announcements of inflation, real economic activity and the trade balance.

We examine the effects on both short- and long-term interest rates. Under the expectations hypothesis of the term structure, any differential response of interest rates reflects differences in the impact of the unexpected change in economic variables on current and predicted future short-term interest rates. ${ }^{8}$ If the expected change in money, inflation, industrial production, etc., is partly transitory, then the effect on the current short-term rate will be larger than on the long-term rate. ${ }^{9}$

\section{Unewperted WONEY}

The evidence in previous studies clearly indicates that the relationship between changes in interest rates and the unexpected part of the money announcement in the early 1980 s is positive. There are three possible explanations for this association: an "expected liquidity" effect; an "expected inflation" effect; and a "real economic activity" effect." susing only these periods to look for changes in the effect of announcements on financial markets becomes increasingly implausible as the changes in operating procedures become more distant in the past.

The lack of generality of the proposition that asset prices are affected only by the unexpected part of announcements is made by, among others, LeRoy (1982), especially pp. 205-08. It can, however, be justified as an approximation (Sims, 1984). The extension to interest rates, an inverse function of the price, can be justified as an approximation.

7Some have found that the expected component of the change in money also exerts a statistically significant effect on changes in interest rates. See, for example, Hein (1985) and Belongia and Sheehan (1987). Several studies have shown, however, that such results may stem from ceriain anomalies in the data. For example, Belongia, Hafer and Sheehan (1986) find that the significance of expected changes in money stems from one observation in which a benchmark revision in the data coincided with a so-called Social Security week. The removal of this observation reduces expected money's coefficient to statistical insignificance. Other researchers, for example, Clark, et al. (1988), also have argued that the inclusion of Social
Security weeks leads to the spurious result that expected changes in money influence interest rate changes. For a discussion of the effecis of Social Security weeks on the observed changes in money, see Hafer (1984).

8The evidence in Flavin (1984) and Campbel and Shiller (1987), for example, indicates that the expectations hypothesis accounts for much of the variation of long-term interest rates relative to short-term rates.

OUnder the expectations hypothesis of the term structure, the change in the long-term interest rate is the sum of the discounted change in expected future interest rates, a term due to the return from holding the bond and terms due to the expected short-term rates appearing in one but not the other bond. See Flavin (1984), p. 231. If the coefficient relating the changes in expected interest rates to the unexpected part of the announcement decreases with term to maturity, then the usual algebra indicates that the response will be less for long-term interest rates.

10 Cornell (1983) and Sheehan (1985) discuss these explanations and provide useful surveys of the evidence. 
The expected liquidity effect is based on the supposition that a larger forecast error is associated with an expectation that the Federal Reserve will engage in more contractionary open market operations in the near future relative to what they would have done otherwise. As a result of the expected contractionary open market operations, near-term interest rates increase. The expectation of higher interest rates in the near future, though, raises current rates to maturity on securities that mature after the expected contractionary open market operations." An unexpected increase in the money stock is thus associated with an increase in interest rates.

An alternative explanation can be cast in terms of expected inflation. Under this explanation, an unexpected increase in money leads economic agents to revise their expectations of future inflation upward. Because nominal interest rates are the sum of the real interest rate and the expected inflation rate, an unexpected increase in expected inflation, ceteris paribus, leads to an increase in nominal interest rates.

The real economic activity effect predicts that interest rates will respond positively to an unexpected money increase. According to this explanation, the money announcement reveals information about money demand in the economy. If the announced stock of money depends on the demand for money, an announced money stock greater than expected indicates that money demand is greater than expected. If the demand for money depends, among other things, on expectations of future real economic activity, an unexpected increase in the money stock reflects an increase in expected real activity. ${ }^{12}$ Because economic activity and real interest rates are positively correlated, an unexpected increase in the money stock is associated with an increase in real and nominal interest rates.

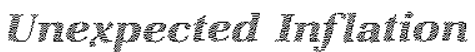

Whether announcements of inflation are related to changes in interest rates due to an effect on expected monetary policy or expected inflation, an announcement that inflation is greater than expected can result in an increase in interest rates. If an announcement of infla-

\footnotetext{
11The current one-day rate also can increase because of intertemporal substitution.

12See Fama (1982).
}

tion greater than expected for the recent period increases expected future inflation, there is a direct effect on the nominal interest rate. On the other hand, with a goal of lower inflation, the Federal Reserve may be expected to offset the higher inflation (or the perception of higher future inflation) by a more restrictive monetary policy. In either case, an unexpected increase in inflation increases nominal interest rates. As for the money stock, the relative effect on shortterm and long-term rates reflects how permanent the change in inflation is expected to be. The more transitory it is, the smaller the relative effect on long-term rates.

\section{Real Activity}

An unexpected increase in real activity raises nominal interest rates through two channels. One is from agents' revised expectations that future real activity will be higher, thus causing expected real interest rates and, hence, nominal rates to increase. The other is from the expected reaction of the Federal Reserve. If economic agents expect the Fed to tighten monetary policy on news of stronger future economic growth, then interest rates can increase because of the expected liquidity effect.

\section{Trade Thence}

The trade balance is exports minus imports. When exports are less than imports, the trade balance is negative, a situation that characterizes most of the 1980s. An announcement of a larger-than-expected trade balance can increase or decrease nominal interest rates. A larger trade balance today is associated with larger trade balances in the future. ${ }^{13}$ Even with this qualification, however, the effect of announcements of trade balances on interest rates is ambiguous. Because the trade balance is the negative of the capital account, a larger trade balance is associated with a smaller balance on capital account. A larger trade balance and a smaller balance on the capital account can be associated with either a decrease in the supply of foreign funds to the United States or a decrease in the demand for funds in the United States. A decrease in the supply of funds would be associated with an increase in interest rates
13There is evidence of positive autocorrelation in the data. Over the sample period used in this paper, the first six values of the autocorrelation function are $0.85,0.85,0.83$, $0.80,0.76$ and 0.75 . 
in the United States. ${ }^{14} \mathrm{~A}$ decrease in demand would be associated with a decrease in interest rates in the United States. Given these two possibilities and no ancillary evidence to support either, the hypothesized effect on nominal interest rates of an unexpected increase in the trade deficit is uncertain.

\section{TUIN DARA}

Daily interest rates on three-month Treasury bills and 30-year Treasury bonds are used in our empirical analysis. These rates are closing quotes supplied by the New York Federal Reserve, calculated as averages of rates reported by primary government security dealers between 3:15 p.m. and 4:00 p.m. Eastern Standard Time. The changes in rates are measured as the difference between the interest rate from one day's close to the next. ${ }^{15}$

To estimate the unexpected part of the announced values of the economic series, we use the initial announced values of the series minus the median response from the survey conducted by MMS International. ${ }^{16}$ This widely used survey polls approximately 50 to 60 government securities dealers weekly, asking them to indicate their expectation of the change in the narrow money stock (M1). At most a week before an announcement of several other economic series, the survey participants also are asked to indicate their forecasts of the change in other series, such as the Consumer Price Index.

In this study, we use the survey forecasts for M1, the Consumer Price Index (CPI), the Producer Price Index (PPI), the industrial production index, the unemployment rate and the trade balance. Because the survey forecasts of the price indexes and industrial production are

14We assume that the United States is not Small relative to the rest of the world.

15The three-month Treasury bill rate is measured using the standard discount interest rate formula. The bond rate is the yield to maturity.

16MMS International and Douglas K. Pearce provided several of the series examined here. Actual changes in the series are taken from relevant government and Federal Reserve publications.

17The F-statistic for testing the hypothesis that the variance of the change in the Treasury bill rate is the same on days with these announcements and days without these announcements is 1.86 with 679 and 1292 degrees of freedom, which has a marginal significance level of less than 0.001 . The F-statistic for testing this hypothesis using the variance of the change in the Treasury bond rate is 1.43, also with 679 and 1292 degrees of freedom and a marginal significance level less than 0.001 . all measured in terms of monthly percentage changes, the unexpected part of the announced values also are measured as a monthly percentage change. The actual and the forecasted unemployment rates are both measured as percentages of the number of unemployed relative to the labor force. The forecasts of M1 and the trade balance are stated in terms of their dollar values. We measure the unexpected part of these variables as the percentage difference between actual and forecasted values relative to the actual values.

Although other economic variables obviously might be included in this analysis, the series used in this study represent a broad range of economic activity, reflecting changes in inflation, real activity and foreign trade. Moreover, the variances of changes in the Treasury bill rate and the Treasury bond rate are greater on the days with these announcements than on other days. ${ }^{17}$

To abstract from the effects of intervening announcements, we include in our regressions changes in interest rates only for those days on which these announcements occur. Since past intervening announcements are prior information and, under rational expectations, are uncorrelated with the current unexpected change, this restriction does not bias our analysis. A future unexpected change in a variable will be currently unknown and, under rational expectations, also would be uncorrelated with the current unexpected change. ${ }^{18}$

Means and standard deviations of the unexpected changes in $M 1$, the price indexes, industrial production, the unemployment rate and the trade balance are presented in table $1 .^{19}$

10 This and the prior statement assume that the forecasts are essentially the same as rational expectations. It is, of course, true that our estimated coefficients can be affected by other events on the same day that are correlated with excluded variables.

19 There are 95 months used in table 1 . There are only 94 observations for the unexpected change in the CPI, because the survey value is missing for the announcement in January 1986. There are 94 observations on the unexpected change in unemployment, because the Treasury bill rate is not avalable for April 5,1985 , when the unemployment rate was announced. Therefore, we do not use this observation. Finally, 93 observations are used for the trade balance, because only 11 values were announced in 1987: and two values were announced on the same day in April 1987. We use just the announcement for the more recent month, March. 


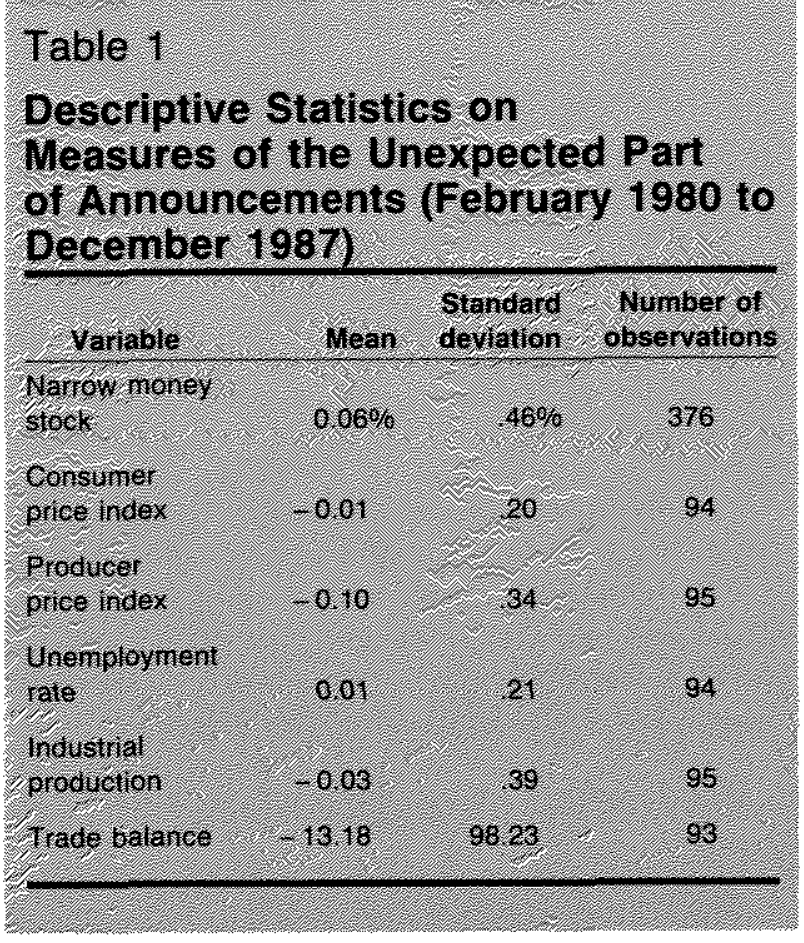

Given the numerical precision of the data and the size of the associated standard errors, all but one of the mean forecast errors lour measures of the unexpected components of the announcements) are not different from zero. For example, the unemployment rate is announced as a percentage, say, $\mathbf{5 . 4}$ percentage points and is forecasted to this same level of numerical precision. A mean of 0.01 is zero within the precision of the data. Only one of the six series, the producer price index, has a mean value that is significantly different, both numerically and statistically, from zero at the 5 percent marginal significance level. This cursory analysis of the data along with other work indicates that these survey data are useful approximations of rational expectations and can be used to estimate the unexpected parts of the series being announced. ${ }^{20}$

An issue that generally is not dealt with when using these data is the fact that the measurement of the expected and actual changes in some of the variables is only in increments of 0.1. That is, forecasts and actual values for the CPI, the PPI and the industrial production index are all collected as monthly percentage changes with only one digit after the decimal point. Because there is a relatively small range of forecast errors at this level of precision, there are a limited number of values that the forecast er. rors actually take. Even so, the information in table 1 indicates that there is sufficient variation to estimate a meaningful relationship between these data and changes in interest rates. ${ }^{21}$

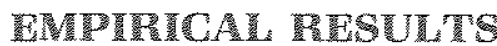

The period used in our analysis runs from February 1980 through December 1987. The beginning of the period is dictated by the lack of survey forecasts of the trade balance prior to that time. The end of the period is dictated by data availability. The vector of observations for each right-hand-side variable includes zeros for those days when a series is not announced.

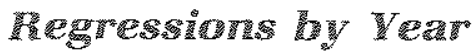

Previous analyses generally estimate equation 1 over all of the available data and for periods corresponding to changes in the Federal Reserve's operating procedures. ${ }^{22}$ Because we are concerned with the pattern of the coefficient estimates on money and other variables over time, we ignore these particular periods and estimate equation 1 for the full period and for each year. Because we have no a priori information that dictates the correct periods, this approach allows us to gauge the effects of the

${ }^{20}$ For other analyses of this data, see, among others, Pearce and Roley (1985).

${ }^{21}$ For example, the forecast errors for the CPI measure of the inflation rate range in increments of 0.7 from -0.6 to 0.5 . The modal error is zero, and the forecast errors are dispersed around this value, not (as would be possible) virtually always .1 or .2 in absolute value. Similar comments apply to the PPI and the industrial production index. The forecast errors of the unemployment rate, also measured to a precision of 0.1 percentage points, range from -0.5 to 0.7 by increments of 0.1 .

${ }^{22}$ As noted above, previous researchers generally delineate sample periods by changes in monetary policy operating procedures. These include the October 6, 1979, shift away

from emphasizing the behavior of the federal funds rate and placing more importance on the behavior of the monetary aggregates and the October 1982 shift back to interest rates. While statistical tests generally do not reject the use of these breakpoints, it has been questioned whether the procedures used are adequate to reject the $a$ priori break point being tested. That is, if October 6,1979 , is not the true breakpoint in the relationship but another relatively close date is, the test procedures used will not reject October 6 as the break. Indeed, evidence presented in Hafer and Sheehan (1989), based on time-varying parameter estimates, indicates that the often-used October 1979 and October 1982 sample breaks are not consistent with the data. 


\section{Table 2}

\begin{tabular}{|c|c|c|c|c|c|c|c|c|}
\hline Perrod & Canstant & umis. & UCP & UPpI & 00 & Uim & Ura: & Furow \\
\hline $1980: 87$ & $\left(\begin{array}{l}0.007 \\
(0.86)\end{array}\right.$ & $\begin{array}{l}0.183 \\
(17.20)\end{array}$ & $\begin{array}{l}0.066 \\
0.581\end{array}$ & $\begin{array}{l}0.082 \\
(1.30)\end{array}$ & $(1,531$ & $\frac{0,019}{(0.33)}$ & $\left(\begin{array}{l}-0.009 \\
(0,38)\end{array}\right.$ & $\begin{array}{l}0.08 \\
2.01\end{array}$ \\
\hline 1980 & $\begin{array}{l}0.016 \\
(0.49)\end{array}$ & $\begin{array}{r}0.284 \\
(3.80)\end{array}$ & $\begin{array}{l}0.129 \\
(0.31)\end{array}$ & $\begin{array}{r}0.249 \\
1.109\end{array}$ & $\begin{array}{l}-0.218 \\
(1.07)\end{array}$ & $\begin{array}{l}0.112 \\
0.56)\end{array}$ & $\begin{array}{r}-0.379 \\
(1.45)\end{array}$ & $\begin{array}{l}0.14 \\
1.73\end{array}$ \\
\hline 1981 & $\begin{array}{r}0.022 \\
(0.66)\end{array}$ & $\begin{array}{r}0.351 \\
(425)\end{array}$ & $\begin{array}{l}0.155 \\
(0.47)\end{array}$ & $\begin{array}{l}0.602 \\
(1.24)\end{array}$ & $=\frac{0.543}{1.10}$ & $\begin{array}{r}0.056 \\
(0.22)\end{array}$ & $\begin{array}{l}0.018 \\
0.36\end{array}$ & $\begin{array}{r}0.14 \\
2.02\end{array}$ \\
\hline $19 a 2$ & $\begin{array}{l}-0.009 \\
0.34)\end{array}$ & $\begin{array}{r}0.227 \\
(2.751\end{array}$ & $\begin{array}{l}0.019 \\
10.061\end{array}$ & $\begin{array}{l}0.187 \\
(0.66)\end{array}$ & $\begin{array}{l}0.112 \\
0.311\end{array}$ & $\begin{array}{l}0.060 \\
(0.50)\end{array}$ & $\begin{array}{l}0.016 \\
10.399)\end{array}$ & $\frac{0.02}{2.46}$ \\
\hline 1983 & $(0.15)$ & $\begin{array}{l}0,154 \\
(5,48)^{2}\end{array}$ & $(0.07)$ & $\begin{array}{l}0.063 \\
(0.54)\end{array}$ & $(2.07)$ & $(0.048$ & $\begin{array}{l}-0.052 \\
(0.44)\end{array}$ & $\begin{array}{l}0.24 \\
1.92\end{array}$ \\
\hline 1984 & $(0.008$ & $\begin{array}{r}0.036 \\
(0.89)\end{array}$ & $\begin{array}{r}-0.011 \\
(0.05)\end{array}$ & $\begin{array}{r}0.027 \\
(0.29)\end{array}$ & $\begin{array}{l}0.072 \\
10.511\end{array}$ & $\begin{array}{l}0.080 \\
(0.94)\end{array}$ & $\begin{array}{r}0.129 \\
(1.00)\end{array}$ & $\begin{array}{r}-0.04 \\
1.99\end{array}$ \\
\hline 1985 & $\begin{array}{l}0.904 \\
(0.40)\end{array}$ & $(0.094)$ & $\frac{-0.010}{(0.03)}$ & $\begin{array}{l}0.064 \\
(0 \mathrm{e} / 5)\end{array}$ & 0.059 & $(0.512$ & $\frac{-0.171}{(0.57)}$ & 2.43 \\
\hline 1986 & $\begin{array}{l}-0.006 \\
(0.051)\end{array}$ & $\begin{array}{l}0.049 \\
(1.59)\end{array}$ & $\begin{array}{l}0.065 \\
(0.48)\end{array}$ & $\begin{array}{r}-0.638 \\
(1.6)\end{array}$ & $\begin{array}{r}-0.107 \\
(1.61)\end{array}$ & $\begin{array}{l}0.173 \\
(2.69)\end{array}$ & $\begin{array}{l}-0.027 \\
(0.29)\end{array}$ & $\begin{array}{l}0.06 \\
2.02\end{array}$ \\
\hline 1987. & $\begin{array}{l}0.034 \\
(2.12)\end{array}$ & $\begin{array}{r}0.004 \\
(0.11)\end{array}$ & $\begin{array}{l}0.083 \\
(0.42)\end{array}$ & $(0.175)$ & $\begin{array}{l}0,050 \\
0.21)\end{array}$ & $(0.63)$ & $\begin{array}{r}0.039 \\
(0.13)\end{array}$ & $\begin{array}{r}-0.00 \\
2.16\end{array}$ \\
\hline
\end{tabular}

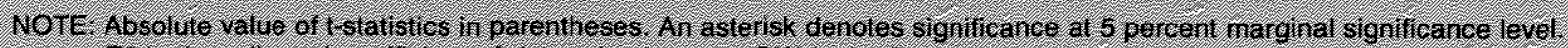

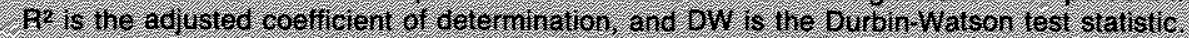

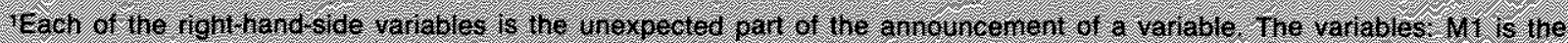

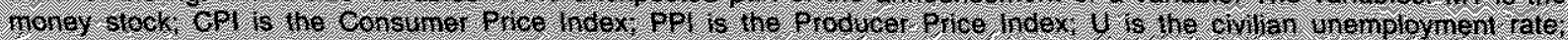

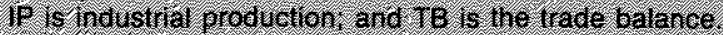

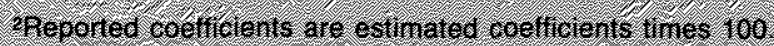

unexpected parts in the announcements over time. While the choice of a year is admittedly arbitrary, it is long enough that some precision in the regression coefficients is possible but short enough that it is unlikely to miss an estimable transitory change in the coefficients. ${ }^{23}$

The regression results are reported in table 2 for the change in the Treasury bill rate. ${ }^{24}$ Based on a 5 percent marginal significance level, only unexpected money (UM1) has a statistically significant coefficient in the full-period regressions. This result does not mean, however, that other economic variables do not influence Treasury bill rate changes during the period. On the contrary, the annual regression results indicate that unexpected unemployment (UU) is marginally statistically significant at the 5 percent level for 1983. It also appears that unexpected changes in the industrial production index (UIP) are associated with increases in the short-term interest rate in 1985 and 1986. In none of the annual regressions, however, do unexpected changes in the Consumer Price Index (UCPI), the Producer Price Index (UPPI) or the trade balance (UTB) have statistically significant coefficients.

The regressions using the change in the 30 year Treasury bond rate are presented in table 3 . The regression for the full period again has a statistically significant estimated coefficient for the unexpected part of M1. The magnitude of

23it is possible, of course, that the estimated coeficients change with each announcement. Without the imposition of constraints on the way that the coefficients change, however, such a specification is not estimable. Our regres. sion coefficients can be interpreted as estimates of the average coefficient in a given year.

24Again note that the estimation uses only unexpected changes in the variables. Since correlations between the expected and unexpected values reveal that the two series are uncorrelated, omitting the expected values does not bias the estimated regression coefficients. 


\section{Table 3}

Change in 30-year Treasury Bond Rate and Unexpected Part of Announcements

\begin{tabular}{|c|c|c|c|c|c|c|c|c|}
\hline Pexors & Gonstain & $01 / 1$ & Ue: & uppl & 11 & 11\% & STar & ravo \\
\hline 1980.67 & $\begin{array}{l}0.003 \\
(0.68)\end{array}$ & $(5,54)$ & $\left(\frac{1092}{40)}\right.$ & $(2,098$ & $\frac{-0.052}{(0.61)}$ & $(0.027$ & $(0,7)$ & $\begin{array}{l}0.05 \\
2.28\end{array}$ \\
\hline 1960 & $\begin{array}{l}0.004 \\
1027 \%\end{array}$ & 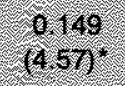 & $\frac{9}{(0.5)}$ & $(1,29)$ & $\begin{array}{c}0,1,10 \\
(0,10)\end{array}$ & $\left(\begin{array}{l}0.163 \\
(7.67)\end{array}\right.$ & $(0,100$ & 204 \\
\hline 1981 & $(1.928$ & $\frac{10 \%}{(2,30)}$ & $(0,8)$ & $\left(\begin{array}{l}0.315 \\
(19)\end{array}\right.$ & $(0,70)$ & $(8,7)$ & $(0.04)$ & $\begin{array}{l}0.03 \\
2.32\end{array}$ \\
\hline 1982 & $(0.009)$ & $(0,049$ & $\frac{0,110}{(0,61)}$ & $\begin{array}{l}0.002 \\
(0.011\end{array}$ & $(0,38)$ & $(0,26)$ & $\left(\frac{6}{6}\right)(5)$ & $\begin{array}{l}2.04 \\
2.59\end{array}$ \\
\hline 1989 & $\begin{array}{r}0,001 \\
(0,08)\end{array}$ & $(6,1)$ & $(0.09)$ & $\begin{array}{l}0.055 \\
(0.97)\end{array}$ & $\begin{array}{l}0,17 \\
(1,50)\end{array}$ & $(0,09)$ & 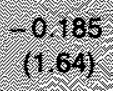 & $\begin{array}{l}0.17 \\
2.15\end{array}$ \\
\hline 1984 & $(0,004)$ & $(0.96)$ & $(1,08)$ & $(0,079)$ & $\frac{-0,1)}{(0,86)}$ & $(0.69)^{2}$ & $\begin{array}{l}0.076 \\
(0.62)\end{array}$ & $\begin{array}{r}-9,02 \\
2.60\end{array}$ \\
\hline 1985 & $(0,20)$ & $(0.016$ & $\frac{0.008}{1002}$ & $\frac{(0,076}{(0,66)}$ & $(0.09)$ & $(1.06)$ & $\begin{array}{r}-0,110 \\
(0,59)\end{array}$ & $\frac{0.03}{2.12}$ \\
\hline 1986 & $(0.001$ & (10.01) & $\begin{array}{r}0.137 \\
(0.79)\end{array}$ & $(0.40)$ & $\begin{array}{l}0.065 \\
(0.87)\end{array}$ & $(1,25)$ & $(0.09)$ & 8.0 .04 \\
\hline 198 & $(0.69)$ & $\begin{array}{r}-0,012 \\
(0.49)\end{array}$ & $(0.015$ & $\begin{array}{l}0.148 \\
(145)\end{array}$ & $(0,84)$ & $(106)$ & $(1,961)$ & 0.07 \\
\hline
\end{tabular}

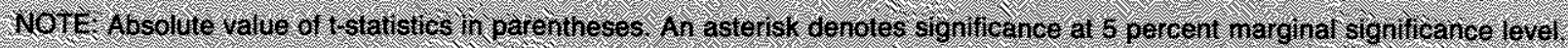

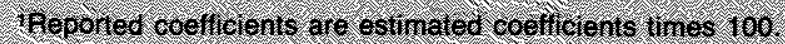

the estimated coefficient is less than one-half that of the short-term Treasury bill rate, a re. sult that is consistent with previous work. ${ }^{25}$ In addition to money announcements, the fullperiod regression suggests that unexpected changes in the PPI have a positive and statistically significant effect on the change in the Treasury bond rate.

Except for 1980, however, the separate annual results provide little evidence that the unexpected changes in these economic variables have much effect on changes in the long-term interest rate. In the results for 1980 , unexpected money and inflation measured by the PPI are statistically significant at the 5 percent level. The coefficient on industrial production is significant at the 5 percent level in 1987. Note, however, that the sign of this estimated coefficient (negative) is incorrect. The estimated coefficient for the unexpected part of the trade balance is significant at the 6 percent marginal significance level in 1987. Interestingly, while the coefficient often is negative, it is positive for 1987 . For the other years, the estimation results are consistent with the proposition that unexpected parts of announcements of variables besides money have little effect on the change in the 30-year rate.

\section{Stabilly Tests}

An important aspect of the regression results in tables 2 and 3 is the variability in the estimated coefficients over time. For example, consider the magnitude of the estimated coefficients on unexpected money from 1980 to 1987 in table 2 . Based on the annual regression results, the estimated coefficient peaks at 0.35 in 1981 and declines to essentially zero in 1987. This result is consistent with the hypothesis that unexpected changes in the money stock are associated with changes in interest rates early in the period but not recently.

${ }^{25}$ For example, see Cornell (1983). 
To investigate whether the estimated coefficients from the various years are statistically different, two tests are conducted. One test determines whether the coefficients for each variable change over time. We test whether each variable's coefficients are equal from 1980 to 1987 . The results of these tests, regardless of the interest rate used are consistent with the hypothesis that only the coefficients on unexpected money vary across years. The F-statistic for unexpected money when the change in the Treasury bill rate is used is 4.46 . The result us ing the Treasury bond rate is an F-statistic of 2.68. Both are statistically significant at less than the 1 percent marginal significance level. ${ }^{26}$ The F-statistics for the remaining variables are insignificant: they almost never even exceed unity. ${ }^{27}$

While this test has reasonable power against the alternative hypothesis that the coefficients are nonzero and change over several of the years, it generally has low power against the alternative that a variable has a nonzero coefficient for a relatively short period such as one year. Consequently, testing the coefficients over single years is a useful additional test.

Testing the hypothesis that a coefficient in any single year is the same as in the remainder of the years provides at most marginal evidence of coefficient instability across the period ${ }^{28} \mathrm{Us}$ ing a 5 percent marginal significance level, tests using the "Treasury bill regressions indicate that the coefficient on the unexpected part of the trade balance in 1980 is statistically different from the coefficients in the rest of the period: the estimated t-statistic is $-2.33^{29}$ With the exception of unexpected money, each of the other coefficients for the Treasury bill rate is equal over time. Besides unexpected money, only the unexpected part of the industrial production index in 1980 has a coefficient for the Treasury bond rate that is statistically different from the remaining years $(t=2.30)$.

These test results are largely consistent with the hypothesis that the response of interest rates to unexpected changes in the variables other than money are constant and equal to zero.

\section{Rolling Regression Estimates}

Breaking the eight years into annual segments to estimate the changes in the coefficients over time may obscure changes that occur during the years. To investigate the evolution of the estimated coefficients, it is worthwhile to examine the coefficients in a relatively unfestricted manner. This can be done by estimating regressions that roll through the sample. Equation 1 is estimated for successive 12 -month periods, adding a month and dropping a month as the estimation of the regression coefficients rolls through the full period ${ }^{30}$ The first 12 -month period begins in February 1980 and ends in January 1981; the last sample ends with December 1987. While using a 12 -month period for the rolling regressions still has an arbitrary element, the estimated coefficients for any 12 -month period are readily available and can be examined. ${ }^{31}$

To show how the estimated coefficients have evolved over the period, the estimated coefficients for both the Treasury bill and Treasury bond rates are plotted in figure 1 . In interpreting these plots, it is important to note that, be-
${ }^{25}$ The results from a standard F-test are consistent with the null hypothesis of overall coefficient stability. In this test, each variable including the constant is allowed to take dif. ferent values for each year. This unrestricted equation is compared with the equation where all estimates are fixed for the full period. The calculated F-statistic for changes in the Treasury bill rate is 1.24 . When the change in the Treasury bond rate is used, the F-statistic is 1.06 . Both of these values are less than the 5 percent critical value. Such a test, however, may mask changes in one or two variables' coefficients. Given the number of variables and time periods, changes in the estimated coefficient for some variable can be swamped by the stability of the others.

27Using the change in the Treasury bill rate, the variables and corresponding F-statistic are: CPI (0.08); PPI (0.95); unemployment $(0.64)$; industrial production $(0.61)$; and trade balance $(0.85)$. Using the change in the Treasury bond rate, the F-statistics are: CPI (0.25); PPI (1.08); unemployment $(0.36)$; industrial production (1.24); and trade balance (0.98).
${ }^{28}$ This test is first run with the coefficients of all other variables allowed to be different, then with the coefficients of all the other variables besides money set equal for al of the years. In the text, we report the results with the coefficients of other variables besides money set equal to each other for all of the years. The results with other coefficients allowed to vary are little different than those discussed.

${ }^{2}$ Given the multiple tests across variables and years, there are good reasons to use a smaller significance level. If one desires an overall 5 percent significance level for all the tests combined, the correct significance level for testing the stability of the coefficients for each year and each variable is about one-tenth of 1 percent.

30Loeys (1985) examines the effects of unexpected money on interest rates in a similar manner.

31 We also estimated the rolling regressions using successive 18 -month periods. There are only minor changes in the results. 


\section{Figure 1}

Panel A

The Coefficients of the Unexpected Component of M1 for the 3-Month Treasury Bill

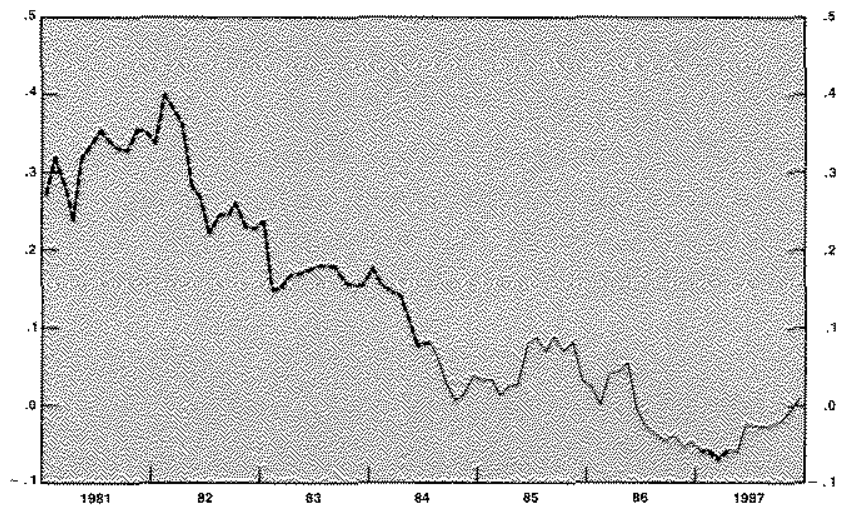

\section{Panel B}

The Coefficients of the Unexpected Component of CPI for the 3-Month Treasury Bill

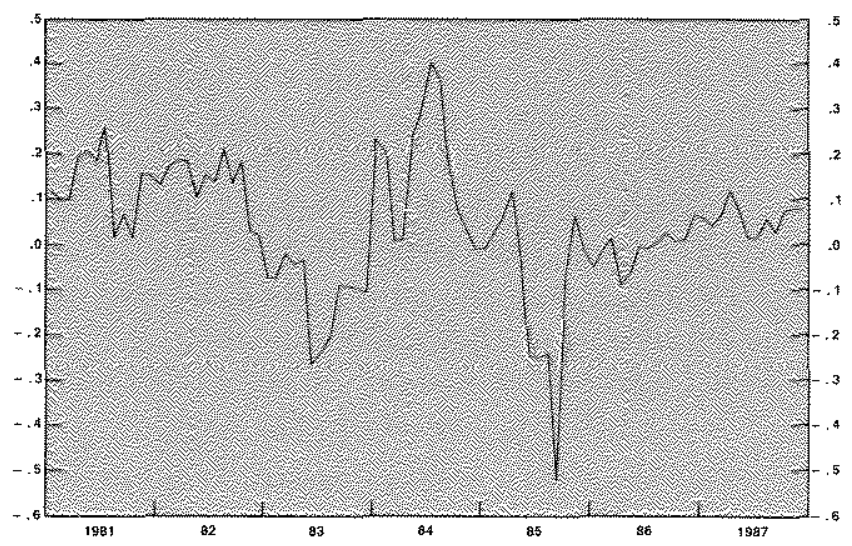

Panel C

The Coefficients of the Unexpected Component of PPI for the 3-Month Treasury Bill

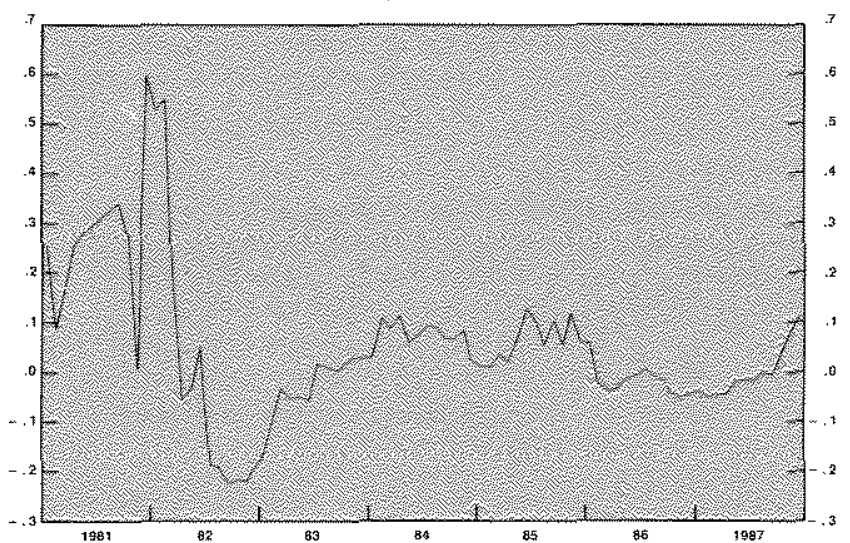

The Coefficients of the Unexpected Component of Mi for the 30-Year Treasury Bond

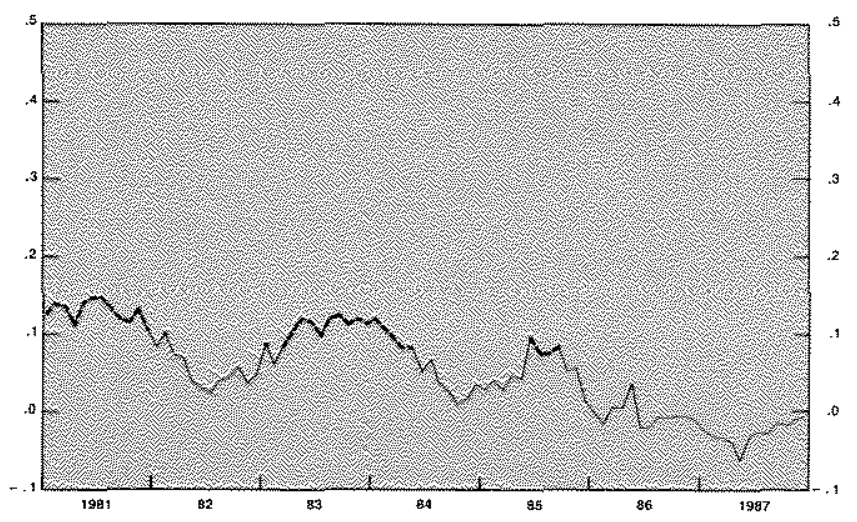

The Coefficients of the Unexpected Component of $\mathrm{CPI}$ for the 30-Year Treasury Bond

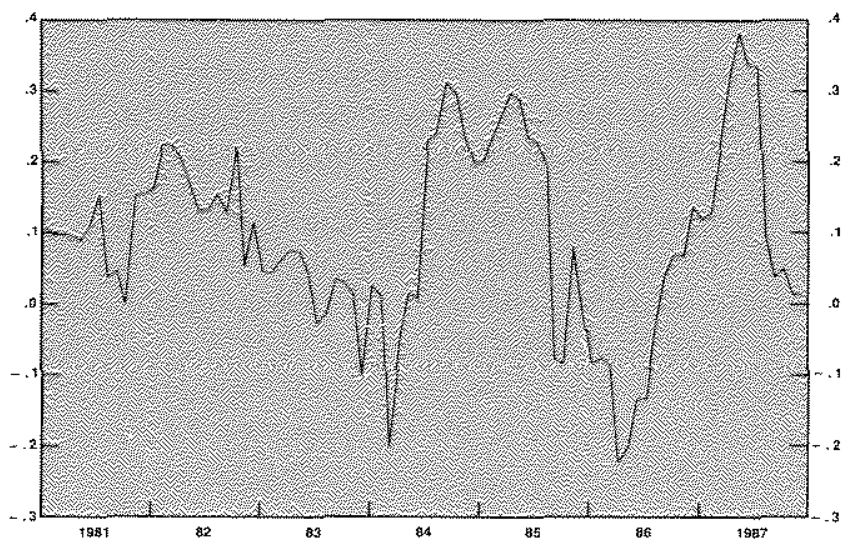

The Coefficients of the Unexpected Component of PPI for the 30-Year Treasury Bond

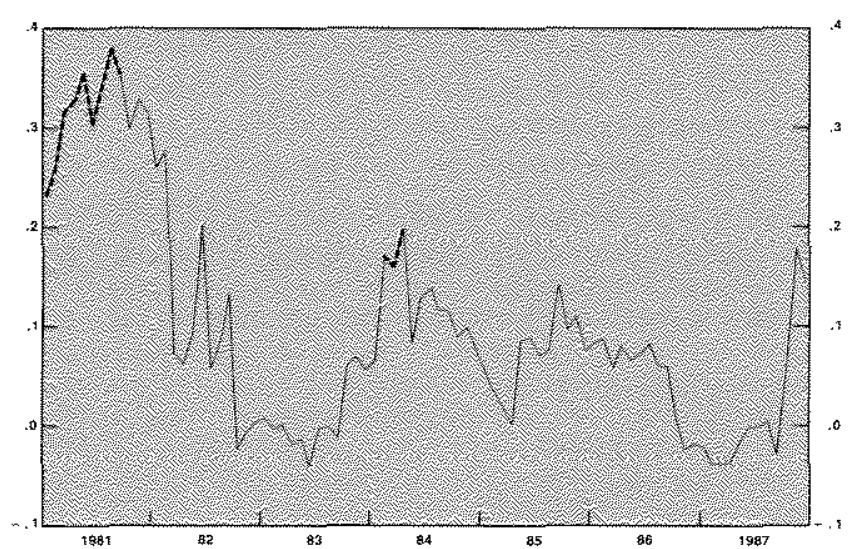

NOTE: A dashed line indicates significance at the 5 percent level. 
-Panel D

The Coefficients of the Unexpected Component of The Unemployment Rate for the Treasury Bill

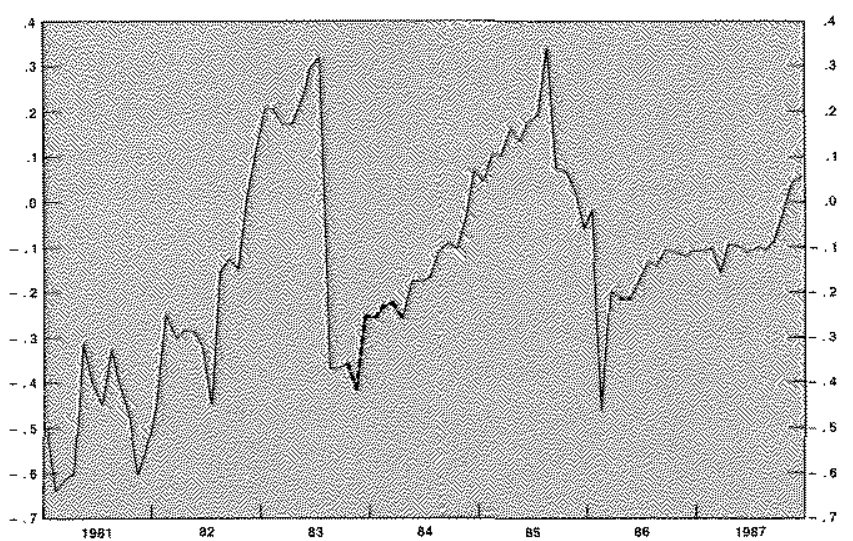

\section{Panel E}

The Coefficients of the Unexpected Component of Industrial Production for the 3-Month Treasury Bill

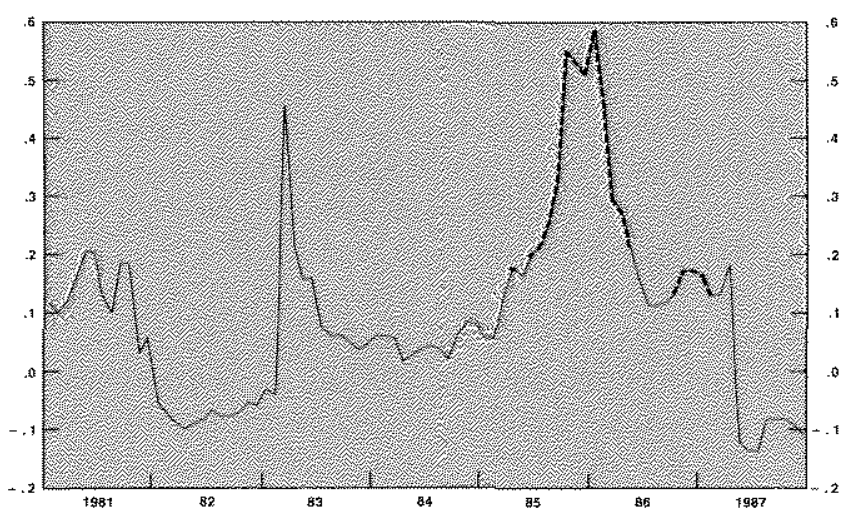

Panel F

The Coefficients of the Unexpected Component of The Trade Balance for the 3-Month Treasury Bill

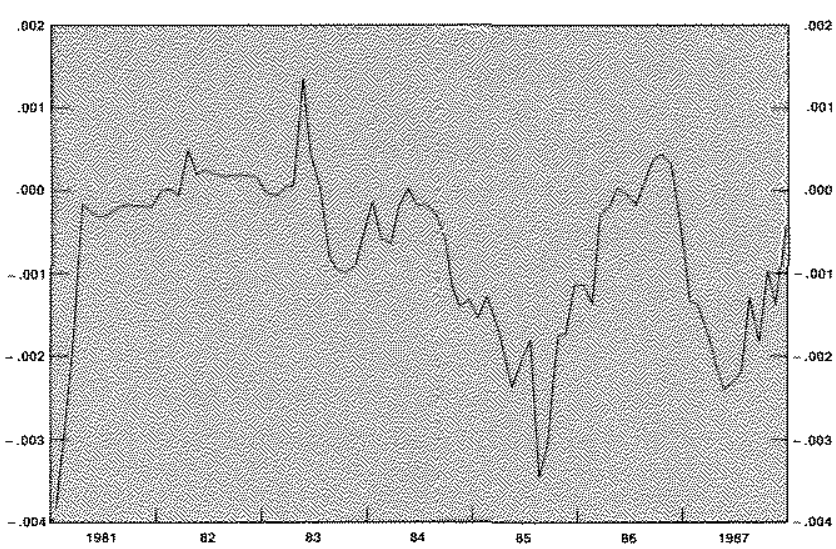

The Coefficients of the Unexpected Component of The Unemployment Rate for the Treasury Bond

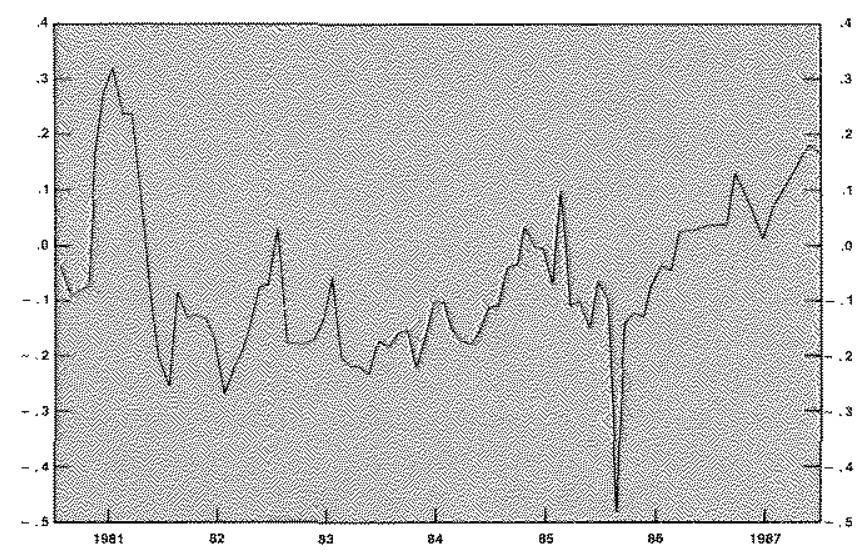

The Coefficients of the Unexpected Component of Industrial Production for the 30-Year Treasury Bond

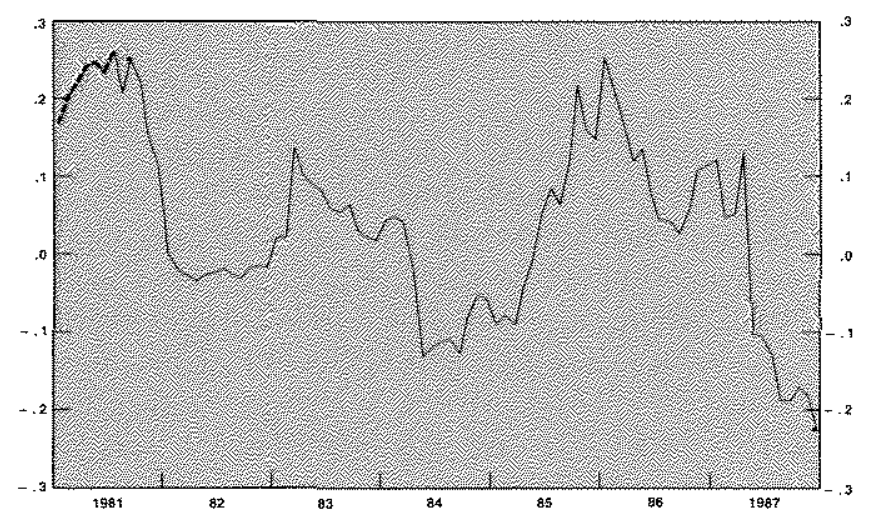

The Coefficients of the Unexpected Component of the Trade Balance for the 30-Year Treasury Bond

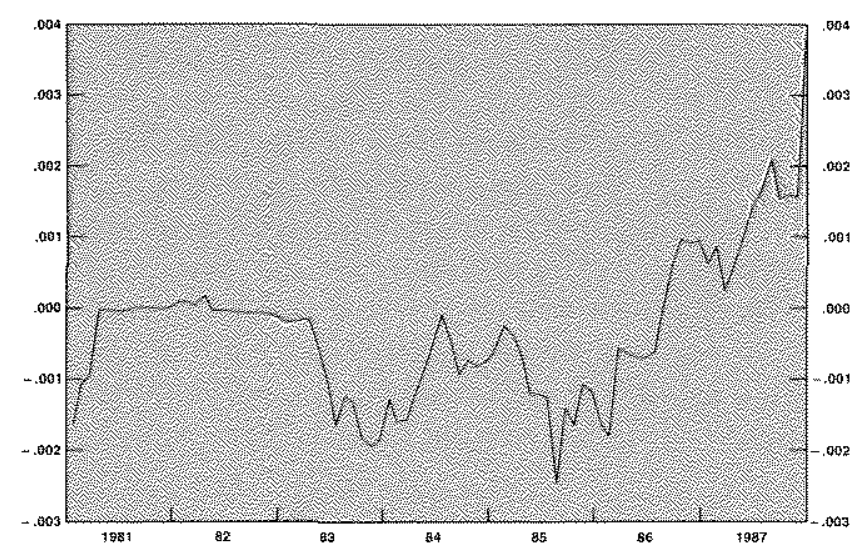


cause common observations in regressions are separated by less than 12 months, the estimated regression coefficients within a 12 -month period are not independent. This implies that some smoothness in the plotted variation of the coefficient estimates is to be expected even if all estimated coefficients are zero and any variation is random.

In addition, the coefficient estimates for the two interest rates are not statistically independent. The simple correlation of the change in the bill rate and the bond rate is 0.658 for 1980 through 1987 on days with announcements, a correlation that is statistically significant at the 5 percent level. This means that, if the estimated coefficient of industrial production, for instance, increases in the regression for the bill rate, the estimated coefficient of industrial production in the regression for the bond rate is likely to increase as well, even if the increase is due to random variation. Despite these caveats, these estimates are useful because they make it possible to examine the inter-year changes in the estimates for all possible dates.

Panel a of figure 1 shows the estimated coefficients on unexpected changes in M1.32 The estimated coefficients in the regression for the bill rate and the bond rate track each other with a larger estimated coefficient for the bill rate until 1984, when the estimated coefficients converge to zero. Finding that the effect of unexpected money on changes in the interest rate becomes smaller after the shift in the Federal Reserve's operating procedure in late 1982 is consistent with previous work. ${ }^{33}$

Panels $b$ and $c$ show the estimated coefficients of unexpected increases in the inflation rate as measured by the CPI and the PPI. In the regressions for the Treasury bill rate, not one estimated coefficient is statistically significant for any 12 -month period using a 5 percent marginal significance level. In the regressions for the Treasury bond rate, only estimated coefficients for the PPI in nine months in 1981 and three months in 1984 are statistically significant using a standard 5 percent marginal significance level. There is no evidence that the unexpected part of announcements of the CPI affect interest rates for any period as long as 12 months from 1980 to 1987. One interpretation consistent with these regression results is that there is some evidence of a relationship between the unexpected part of inflation as measured by the Producer Price Index in 1980, but little afterwards. Such an interpretation requires that the point estimates of the regression coefficients be view. ed as indications that the unexpected parts of the announcements had stronger implications for inflation over a period longer than the three-month maturity of the Treasury bill rate.

Real activity is represented by the unemployment rate (an inverse indicator) and industrial production. The estimated coefficients of the unemployment rate are presented in panel $d$. In the regressions for the Treasury bill rate, the coefficient of the unemployment rate is negative and statistically significant at the 5 percent marginal significance level during late 1983 and early 1984. While the estimated coefficient for the bond rate is not statistically significant during this period, the negative and smaller (in magnitude) coefficient is consistent with the hypothesis that the unexpected part of announcements of the unemployment rate affect interest rates in this period. The estimated coefficients for industrial production (panel e) also provides some evidence consistent with the hypothesis that announcements of it have affected interest rates. In particular, from mid-1985 through much of 1986, the Treasury bill and bond rates both have sharply increasing estimated coefficients on unexpected increases in industrial production. For the Treasury bill rate equations, these coefficients are significant at the 5 percent level. The positive sign is consistent with a rationalization in terms of monetary policy, with higher growth being followed by expectations of relatively contractionary monetary policy, and in terms of expected higher future growth signaling higher real interest rates.

Finally, the estimated coefficients for the trade balance, shown in panel $f$, never provide much support for a systematic relationship except perhaps at the start of the sample. Not one of the 168 estimated coefficients in the regressions for the bill and bond rates is statistically significant using a 5 percent marginal significance level.

\section{CONGUSBREN}

How do financial markets respond to the unexpected part of announcements of govern-

33 See, for example, Hardouvelis (1987) and Hafer and Sheehan (1989).
32Dashed lines denote statistical significance at standard 5 percent marginal significance level. 
ment statistics? Based on the evidence presented in this article, the answer is, very little. Using regression analysis, statistical tests of coefficient stability and rolling regressions to detect coefficient variability from 1980 to 1987 , we find that only the unexpected changes in the money stock have a systematic effect on interest rates. Even then, it appears that the significant effects peter out by late 1982 .

For none of the other variables examined do we find evidence of a reliable effect on interest rates over the period. This set of variables includes measures of inflation, real economic activity and foreign trade. Failing to find any systematic relationship between interest rate changes and these non-monetary variables has two implications. One is that explanations of the response of interest rates to monetary announcements that emphasize changes in economic agents' expectations of future inflation and real economic activity may be off the mark for 1980 through 1982. If these explanations were correct, such effects should be evident when inflation and real variables themselves are used. Our results, however, reveal little effect from the unemployment rate or industrial production. Theories that are premised on the response of interest rates to expected changes in monetary policy are more consistent with our empirical results.

The other implication concerns the effect on interest rates perceived by financial market analysts when government statistics are announced. We find no consistent response of interest rates, either short term or long term, to unexpected changes in the different non-monetary variables. We do find evidence consistent with the hypothesis that the unexpected parts of announcements of the Producer Price Index in 1980, the unemployment rate in 1983 and industrial production in 1980, 1985 and 1986 are associated with changes in interest rates. The relative infrequency of these significant effects can be interpreted in one of two ways. The first is that, of the 80 estimated annual coefficients, it is hardly surprising that five are statistically significant at the 5 percent marginal significance level. A conclusion that all of the coefficients are zero is therefore consistent with the results. The second is that, except for announcements of the money stock in the early 1980s, responses of interest rates to announcements are episodic, short-lived affairs.

\section{W}

Belongia, Michael T., R, W. Hafer, and Richard G. Sheehan. "On the Temporal Stability of the Interest Rate-Weekly Money Relationship," Review of Economics and Statistics (August 1988), pp. 516-20.

"A Note on the Temporal Stability of the Interest Rate-Weekly Money Relationship," Working Paper 86-002, Federal Reserve Bank of St. Louis (1986).

Belongia, Michael T, and Richard G. Sheehan. "The Intormational Efficiency of Weekly Money Announcements: An Econometric Critique," Journal of Business and Economic Statistics (July 1987), pp. 351-56.

Campbell, John Y., and Robert J. Shiller. "Cointegration and Tests of Present Value Models," Journal of Political Economy (October 1987), pp. 1062-88.

Clark, Truman A., Douglas H. Joines, and G, Michael Phillips. "Social Security Payments, Money Supply Announcements, and interest Rates," Journal of Monetary Economics (Septernber 1988), pp. 257778.

Coneli, Bradford. "The Money Supply Announcements Puzzle: Review and Interpretation," American Economic Review (September 1983), pp. 644-57.

Fama, Eugene E. "Inflation, Output, and Money," Journal of Business (April 1982), pp. 201-32.

Flavin, Marjorie. "Time Series Evidence on the Expectations Hypothesis of the Term Structure," in Karl Brunner and Allan H. Meltzer, eds., Monetary and Fiscal Policies and Their Applications, Carnegie-Rochester Conference Series on Public Policy, Volume 20 (Amsterdam: North-Holland, 1984).

Gilbert, R. Alton, "Operating Procedures for Conducting Monetary Policy," this Review (February 1985), pp. 13-21.

Hafer, R. W. "Comparing Time-Series and Survey Forecasts of Weekly Changes in Money: A Methodological Note," Journal of Finance (September 1984), pp. 1207-13.

Hafer, R.W., and Richard G. Sheehan. "On the Response of Interest Rates to Unexpected Weekly Money; Are Policy Changes Important?" Federal Reserve Bank of St. Louis Research Paper 87-005 (revised, February 1989).

Hardouvelis, Gikas A. "Macroeconomic Information and Stock Prices;" Journal of Economics and Business (May 1987), pp. 131-40.

Hein, Scott E. "The Response of Short-Term Interest Rates to Weekly Money Announcements: A Comment:" Journal of Money, Credit and Banking (May 1985), pp. 264.71.

LeRoy, Stephen F". "Expectations Models of Asset Prices: A Survey," Journal of Finance (March 1982), pp. 185-217.

Loeys, Jan G. "Changing Interest Rate Responses to Money Announcements: 1977-83," Journal of Monetary Economics (May 1985), pp. 323-32.

Pearce, Douglas K, and V. Vance Roley. "Stock Prices and Economic News," Journal of Business (January 1985), pp. 49-67. 
Sease, Douglas R. "Trade Deficit's Impact Declines Despite Jitters," Wall Street Joumal, February 21, 1989.

Sheehan, Richard G. 'Weekly Money Announcements? New Information and its Effects," this Review (August/September 1985), pp. 25-34.

Shiller, Robert J., John Y. Campbell, and Kermit L. Schoenholiz. "Forward Rates and Future Folicy: Interpreting the Term Structure of Interest Rates," Brookings Papers on Economic Activity (1: 1983), pp. 173-217.
Sims, Christopher A. "Martingale-like Behavior of Prices and Interest Rates," University of Minnesota Center for Economic Research Discussion Paper No. 205.

Thornton, Daniel L. "Why Do Market Interest Pates Respond to Money Announcements?" Federal Reserve Bank of St. Louis Research Paper No. 88-002, 1988.

- "The Borrowed-Reserves Operating Procedure: Theory and Evidence," this Review (January/February 1988), pp. 30-54.

Wallace, Anise C. "The Numbers that Move the Market," New York Times, June 5, 1988. 